\title{
Front Matter: Volume 8576
}

, "Front Matter: Volume 8576," Proc. SPIE 8576, Optical Fibers and Sensors for Medical Diagnostics and Treatment Applications XIII, 857601 (28 March 2013); doi: 10.1117/12.2024946

SPIE. Event: SPIE BiOS, 2013, San Francisco, California, United States 


\title{
PROGRESS IN BIOMEDICAL OPTICS AND IMAGING
}

\section{Optical Fibers and Sensors for Medical Diagnostics and Treatment Applications XIII}

\author{
Israel Gannot \\ Editor
}

2-3 February 2013

San Francisco, California, United States

Sponsored and Published by

SPIE 
The papers included in this volume were part of the technical conference cited on the cover and title page. Papers were selected and subject to review by the editors and conference program committee. Some conference presentations may not be available for publication. The papers published in these proceedings reflect the work and thoughts of the authors and are published herein as submitted. The publisher is not responsible for the validity of the information or for any outcomes resulting from reliance thereon.

Please use the following format to cite material from this book:

Author(s), "Title of Paper," in Optical Fibers and Sensors for Medical Diagnostics and Treatment Applications XIII, edited by Israel Gannot, Proceedings of SPIE Vol. 8576 (SPIE, Bellingham, WA, 2013) Article CID Number.

ISSN: $1605-7422$

ISBN: 9780819493453

Published by

SPIE

P.O. Box 10, Bellingham, Washington 98227-0010 USA

Telephone +1 3606763290 (Pacific Time) · Fax +1 3606471445

SPIE.org

Copyright @ 2013, Society of Photo-Optical Instrumentation Engineers.

Copying of material in this book for internal or personal use, or for the internal or personal use of specific clients, beyond the fair use provisions granted by the U.S. Copyright Law is authorized by SPIE subject to payment of copying fees. The Transactional Reporting Service base fee for this volume is $\$ 18.00$ per article (or portion thereof), which should be paid directly to the Copyright Clearance Center (CCC), 222 Rosewood Drive, Danvers, MA 01923. Payment may also be made electronically through CCC Online at copyright.com. Other copying for republication, resale, advertising or promotion, or any form of systematic or multiple reproduction of any material in this book is prohibited except with permission in writing from the publisher. The CCC fee code is $1605-7422 / 13 / \$ 18.00$.

Printed in the United States of America.

Publication of record for individual papers is online in the SPIE Digital Library.

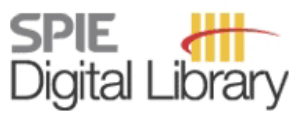

SPIEDigitalLibrary.org

Paper Numbering: Proceedings of SPIE follow an e-First publication model, with papers published first online and then in print and on CD-ROM. Papers are published as they are submitted and meet publication criteria. A unique, consistent, permanent citation identifier (CID) number is assigned to each article at the time of the first publication. Utilization of CIDs allows articles to be fully citable as soon as they are published online, and connects the same identifier to all online, print, and electronic versions of the publication. SPIE uses a six-digit CID article numbering system in which:

- The first four digits correspond to the SPIE volume number.

- The last two digits indicate publication order within the volume using a Base 36 numbering

system employing both numerals and letters. These two-number sets start with 00, 01, 02, 03, 04, $05,06,07,08,09,0 A, 0 B \ldots 0 Z$, followed by 10-1Z, 20-2Z, etc.

The CID Number appears on each page of the manuscript. The complete citation is used on the first page, and an abbreviated version on subsequent pages. Numbers in the index correspond to the last two digits of the six-digit CID Number. 


\title{
Contents
}

\author{
vii Conference Committee
}

SESSION 1 OPTICAL FIBERS AND SENSORS I

857602 Fabrication of a rugged polymer-coated silver hollow fiber with a vitreous film for the infrared [8576-1]

K. Iwai, Sendai National College of Technology (Japan); M. Miyagi, Tohoku Institute of Technology (Japan); Y.-W. Shi, Fudan Univ. (China); Y. Matsuura, Tohoku Univ. (Japan)

857603 Focused light delivery and all optical scanning from a multimode optical fiber using digital phase conjugation [8576-2]

I. N. Papadopoulos, S. Farahi, C. Moser, D. Psaltis, Ecole Polytechnique Fédérale de Lausanne (Switzerland)

857604 Dual-modality fiber-optic imager (DFOI) for intracellular gene delivery in human cervical cancer cell [8576-3]

J. Cha, J. Zhang, S. Gurbani, M. Li, J. U. Kang, Johns Hopkins Univ. (United States)

857605 Numerical analysis of the diffusive mass transport in brain tissues with applications to optical sensors [8576-4]

A. P. Neculae, Univ. of West Timisoara (Romania); A. Otte, D. Curticapean, Hochschule Offenburg (Germany)

857606 Effects of sterilization methods on key properties of specialty optical fibers used in medical devices [8576-5]

A. A. Stolov, B. E. Slyman, D. T. Burgess, A. S. Hokansson, J. Li, R. S. Allen, OFS Specialty Photonics Div. (United States)

857607 Laser-induced damage to large core optical fiber by high peak power laser [8576-6] X. Sun, J. Li, OFS Specialty Photonics Div. (United States)

SESSION 2 OPTICAL FIBERS AND SENSORS II

857608 Flexible delivery of Er:YAG radiation at $2.94 \mu \mathrm{m}$ with novel hollow-core silica glass fibres: demonstration of tissue ablation [8576-7]

A. Urich, R. R. J. Maier, Heriot-Watt Univ. (United Kingdom); J. C. Knight, F. Yu, Univ. of Bath (United Kingdom); D. P. Hand, J. D. Shephard, Heriot-Watt Univ. (United Kingdom)

8576 OB Dual-channel fiber-probe for simultaneous imaging of swept source optical coherence tomography and fluorescence spectroscopy [8576-10]

E. J. Min, J. H. Lee, J. G. Shin, Gwangju Institute of Science and Technology (Korea, Republic of); S.-M. Kwon, Wonkwang Univ. (Korea, Republic of); H. You, Gwangju Institute of Science and Technology (Korea, Republic of); J.-H. Yoon, Wonkwang Univ. (Korea, Republic of); Y.-C. Kim, B. H. Lee, Gwangju Institute of Science and Technology (Korea, Republic of) 
8576 OD Real-time depth-resolved Raman endoscopy for in vivo diagnosis of dysplasia in Barrett's esophagus [8576-12]

M. S. Bergholt, W. Zheng, National Univ. of Singapore (Singapore); K. Y. Ho, K. G. Yeoh,

M. Teh, J. B. Y. So, National Univ. of Singapore and National Univ. Hospital System

(Singapore); Z. Huang, National Univ. of Singapore (Singapore)

8576 OE Microstructured optical fiber Bragg grating sensor for DNA detection [8576-13]

A. Candiani, S. Giannetti, M. Sozzi, E. Coscelli, F. Poli, A. Cucinotta, A. Bertucci, R. Corradini, Univ. degli Studi di Parma (Italy); M. Konstantaki, Foundation for Research and Technology - Hellas (Greece); W. Margulis, Acreo AB (Sweden); S. Pissadakis, Foundation for Research and Technology - Hellas (Greece); S. Selleri, Univ. degli Studi di Parma (Italy)

8576 OF Hollow core photonic crystal fiber as a robust Raman biosensor [8576-14]

A. Khetani, A. Momenpour T. Monfared, V. S. Tiwari, H. Anis, J. Riordon, M. Godin, Univ. of Ottawa (Canada)

8576 OG Augmenting convection-enhanced delivery through simultaneous co-delivery of fluids and laser energy with a fiberoptic microneedle device [8576-15]

R. L. Hood, T. Ecker, R. Andriani, J. Robertson, J. Rossmeisl, C. G. Rylander, Virginia Polytechnic Institute and State Univ. (United States)

\section{SESSION 4 OPTICAL FIBERS AND SENSORS IV}

8576 ol Ball lens fiber optic sensor based smart handheld microsurgical instrument [8576-17] C. Song, Johns Hopkins Univ. (United States); P. L. Gehlbach, Johns Hopkins School of Medicine (United States); J. U. Kang, Johns Hopkins Univ. (United States)

8576 0J Non-circular core, all silica fibers for irradiation and sensing medical applications [8576-18] B. J. Skutnik, CeramOptec Industries, Inc. (United States) and Biolitec, Inc. (United States)

8576 OK Optical fibers for $355 \mathrm{~nm}$ pulsed lasers and high-power broadband light sources [8576-19] J. Heimann, Technische Hochschule Mittelhessen (Germany); K.-F. Klein, C. P. Gonschior, Technische Hochschule Mittelhessen (Germany) and TransMIT GmbH (Germany); M. Klein, TransMIT GmbH (Germany); G. Hillrichs, Hochschule Merseburg (Germany)

$8576 \mathrm{OL}$ Fluorescence image-guided photodynamic therapy of cancer cells using a scanning fiber endoscope [8576-20]

M. H. Woldetensae, Univ. of Washington (United States); M. R. Kirshenbaum, Univ. of Washington (United States) and The Boeing Co. (United States); G. M. Kramer, Nortis, Inc. (United States); L. Zhang, E. J. Seibel, Univ. of Washington (United States)

$8576 \mathrm{ON}$ Monitoring the impact of pressure on the assessment of skin perfusion and oxygenation using a novel pressure device [8576-22]

J. C. Ramella-Roman, T. Ho, D. Le, P. Ghassemi, T. Nguyen, The Catholic Univ. of America (United States); A. Lichy, S. Groah, National Rehabilitation Hospital (United States) 
857600 Design and fabrication of multilayer thin film coated hollow waveguides for enhanced infrared radiation delivery [8576-33]

C. M. Bledt, Rutgers Univ. (United States) and Brown Univ. (United States); J. E. Melzer,

J. A. Harrington, Rutgers Univ. (United States)

8576 OR Optical fiber probe for all-optical photoacoustic measurement [8576-25]

Y. Miida, Y. Matsuura, Tohoku Univ. (Japan)

8576 OS Hollow waveguide with multiple dielectric layer for infrared cavity-ring-down spectroscopy [8576-26]

R. Ichikawa, T. Katagiri, Y. Matsuura, Tohoku Univ. (Japan)

8576 OT Measurement of blood glucose by infrared spectroscopy using hollow-optical fiber probe [8576-27]

Y. Tanaka, S. Kino, Y. Matsuura, Tohoku Univ. (Japan)

$85760 \mathrm{U} \quad$ Whispering gallery mode aptasensors for detection of blood proteins [8576-30]

L. Pasquardini, Fondazione Bruno Kessler Ctr. for Materials and Microsystems (Italy);

S. Berneschi, Ctr. Studi e Ricerche E. Fermi (Italy) and Nello Carrara Institute of Applied Physics, CNR (Italy); A. Barucci, F. Cosi, Nello Carrara Institute of Applied Physics, CNR (Italy); M. Insinna, Univ. degli Studi di Florence (Italy); L. Lunelli, Fondazione Bruno Kessler Ctr. for Materials and Microsystems (Italy) and IBF-CNR, Univ. degli Studi di Trento (Italy); G. Nunzi Conti, Nello Carrara Institute of Applied Physics, CNR (Italy); C. Pederzolli, Fondazione Bruno Kessler Ctr. for Materials and Microsystems (Italy); S. Salvadori, Univ. degli Studi di Florence (Italy); S. Soria, Nello Carrara Institute of Applied Physics, CNR (Italy)

8576 OV Potential for using mid-infrared light for non-invasive, early-detection of skin cancers in vivo [8576-34]

A. B. Seddon, The Univ. of Nottingham (United Kingdom)

\section{POSTER SESSION}

8576 0X Measurement of glucose concentration by fiber-optic surface plasmon resonance sensor [8576-29]

D. Li, R. Zhu, P. Wu, J. Wu, K. Xu, Tianjin Univ. (China)

8576 OY Interventional operation OCT probe with the function of real time temperature monitoring [8576-31]

Y. Guo, Qiqihar Univ. (China) and Johns Hopkins Univ. (United States); L. Wei, Qiqihar Univ. (China); X. Liu, Johns Hopkins Univ. (United States)

$85760 Z$ Monitoring of the degradation in the rat's articular cartilage inducing osteoarthritis using common-path Fourier-domain optical coherence tomography [8576-32]

D. H. Shin, S. H. Park, B. Y. Kim, M. Y. Lee, H. K. Baik, J. H. Seo, Chonbuk National Univ. (Korea, Republic of); J. U. Kang, Johns Hopkins Univ. (United States); C. G. Song, Chonbuk National Univ. (Korea, Republic of)

Author Index 


\title{
Conference Committee
}

\author{
Symposium Chairs
}

James Fujimoto, Massachusetts Institute of Technology (United States)

R. Rox Anderson, Wellman Center for Photomedicine, Massachusetts General Hospital (United States) and Harvard School of Medicine (United States)

Program Track Chairs

Tuan Vo-Dinh, Duke University (United States)

Anita Mahadevan-Jansen, Vanderbilt University (United States)

Conference Chair

Israel Gannot, Tel Aviv University (Israel)

Conference Program Committee

James P. Clarkin, Polymicro Technologies, A Subsidiary of Molex Inc. (United States)

Ilko K. Ilev, U.S. Food and Drug Administration (United States)

Jin U. Kang, Johns Hopkins University (United States)

Karl-Friedrich Klein, Technische Hochschule Mittelhessen (Germany)

Pierre Lucas, The University of Arizona (United States)

Yuji Matsuura, Tohoku University (Japan)

Angela B. Seddon, The University of Nottingham (United Kingdom)

\section{Session Chairs}

1 Optical Fibers and Sensors I

Angela B. Seddon, The University of Nottingham (United Kingdom)

2 Optical Fibers and Sensors II

Pierre Lucas, The University of Arizona (United States)

3 Optical Fibers and Sensors III

James P. Clarkin, Polymicro Technologies, A Subsidiary of Molex Inc. (United States)

4 Optical Fibers and Sensors IV

Yuji Matsuura, Tohoku University (Japan)

5 Optical Fibers and Sensors $V$

Karl-Friedrich Klein, Technische Hochschule Mittelhessen (Germany)

Moinuddin Hassan, U.S. Food and Drug Administration (United States) 